Article

\title{
Formation and Evolution of Inclusions with Different Adding Order of Magnesium and Sulfur in Al-Killed Free-Cutting Steel
}

\author{
Yi Min, Qingsong Zhang * $\mathbb{D}$, Haisheng $\mathrm{Xu}$, Jiujian $\mathrm{Xu}$ and Chengjun Liu \\ Key Laboratory for Ecological Metallurgy of Multimetallic Ores (Ministry of Education), School of Metallurgy, \\ Northeastern University, Shenyang 110819, Liaoning, China; miny@smm.neu.edu.cn (Y.M.); \\ 18341254025@163.com (H.X.); xujiujian1994@163.com (J.X.); liucj@smm.neu.edu.cn (C.L.) \\ * Correspondence: zhqs8692921@163.com; Tel.: +86-024-83681478
}

Received: 15 November 2018; Accepted: 11 December 2018; Published: 14 December 2018

\begin{abstract}
To reveal the effect of adding order of magnesium and sulfur on the evolution of inclusions in Al-killed free-cutting steel, both deoxidized experiments and thermodynamic calculations were carried out in this paper. The samples, which were extracted from the liquid steel at different time after magnesium and sulfur addition, were analyzed by scanning electron microscopy and energy dispersive spectroscopy. The results showed that the adding order had a significant influence on the formation and evolution of inclusions. In the case of magnesium added before sulfur, $\mathrm{MgO}$ formed immediately after magnesium addition and then transformed to spinel accompanied by MeS $\left(\mathrm{Mg}_{0.9} \mathrm{Mn}_{0.1} \mathrm{~S}\right)$ after sulfur addition. In the case of sulfur added prior to magnesium, $\mathrm{MgO}$ and $\mathrm{MeS}$ precipitated simultaneously after magnesium addition. During the equilibrium solidification, the transformation of $\mathrm{MgO}$ to spinel was calculated to take place before $\mathrm{MnS}$ precipitated from the saturated liquid steel.
\end{abstract}

Keywords: magnesium treatment; resulfurization; adding order; inclusions; thermodynamics; free-cutting steel

\section{Introduction}

Non-metallic inclusions have a great influence on the mechanical properties and machinability of steel. For example, manganese sulfide is usually used to improve machinability in free-cutting steel as the stress concentration source [1-4]. However, the deformation of manganese sulfide along with the rolling direction deteriorates the mechanical properties of the steel $[5,6]$. The control of the sulfide inclusions morphology is vital for balancing the mechanical properties and machinability of free cutting steel.

In order to control sulfide inclusions, some strong sulfide-forming elements were added into liquid steel to form more stable sulfide inclusions with high melting point. Experimental results of Luyckx et al. [7] verified that the rare earth additives could be used to achieve the control of sulfide morphology in aluminum killed steels. Jiang et al. [8] quantitatively studied the modification of sulfide inclusions by calcium in a resulfurized alloy steel, and the results showed that the proportion of MnS is reduced while that of $(\mathrm{Ca}, \mathrm{Mn}) \mathrm{S}$ raised as the ratio of $\mathrm{Ca} / \mathrm{S}$ in steel increased. The tendency for zirconium to form zirconium sulfide inclusions or zirconium manganese sulfides in steel was early reported by Field et al. [9] and Koch et al. [10]. A discussion of the degree of sulfide shape control by zirconium addition was published by Pollare et al. [5]. The degree of sulfide shape control was improved by increasing the zirconium content or reducing the manganese content of the steel.

In the consideration of sulfide stability, magnesium is also a strong sulfide forming element and magnesium treatment is expected to achieve the control of sulfide shape in free-cutting steel. 
However, the reports about sulfide modification by magnesium are very limited. Numerous studies were carried out to study the effect of magnesium on the desulfurization and the control of oxide inclusions. Yang et al. [11] studied the desulfurization of molten iron with magnesium vapor and found that when the magnesium concentration reached the maximum, the sulfur concentration became very low. Hosohara et al. [12] investigated the desulfurization mechanism with magnesium and the results implied that desulfurization rate is controlled by the diffusion of $\mathrm{Mg}$ and $\mathrm{S}$. In the work of Chen et al. [13], magnesium was used to further decrease the oxygen content and improve the cleanness of traditional aluminum-killed steel. Experimental results showed that the dissolved oxygen in steel could be lower than 0.0001 pct. with the magnesium content higher than 0.0010 pct. In order to reveal the effects of magnesium on the evolution of inclusions, the deoxidized experiments were carried out by Zhang et al. [14] and the results found that magnesium could well control the size of oxide inclusions in Mn-Si-Al deoxidized melts. Furthermore, Park et al. [15] reviewed the control of $\mathrm{MgO} \cdot \mathrm{Al}_{2} \mathrm{O}_{3}$ in stainless steels and Zhang et al. [16] calculated the stability diagram of Mg-Al-O system to predict the formation of inclusions during magnesium treatment. In the production of resulfurized free-cutting steel, sulfur is usually added up to a maximum of 0.4 mass pct., which is significantly different with other steels. However, the effect of magnesium treatment on sulfide inclusions is still unclear, especially the influence of treatment time on the evolution of inclusions in high sulfur-containing steel.

In the current article, laboratory experiments were performed to reveal the influences of magnesium and sulfur adding order on the compositions of inclusions in Al-killed resulfurized free-cutting steel. Samples collected at different time were analyzed by field emission scanning electron microscopy and energy dispersive spectroscopy. Meanwhile, the thermodynamic calculations for Fe-Mg-Al-Mn-O-S system were conducted, and the calculation results were performed to discuss the formation and evolution process of inclusions.

\section{Experimental Methods}

\subsection{Experimental Procedure}

Two sets of experiments (Exp. A and Exp. B) were carried out in a tube furnace, heated by $\mathrm{MoSi}_{2}$ rods, as shown in Figure 1. MgO crucible was used to contain the molten steel. For each experiment, about $450 \mathrm{~g}$ industrial pure iron and $\mathrm{Mn}$-Fe alloy were heated to $1600{ }^{\circ} \mathrm{C}$ under high pure argon atmosphere (99.99 pct.). Subsequently, pure aluminum was added into the molten steel for deoxidization. Thereafter, Ni-Mg alloy (Alloy 1) was added into the liquid steel followed by FeS (Alloy 2) in Exp. A, while FeS (Alloy 1) was added before Ni-Mg alloy (Alloy 2) in Exp. B. 5 min later after Alloy 1 added, the first sample (S1) were sucked out by a quartz tube ( $\phi 5 \mathrm{~mm})$ and then quenched by inserting into an ice-water bath. Another three samples (S2, S3, S4) were taken respectively at $1 \mathrm{~min}$, $5 \mathrm{~min}$ and $10 \mathrm{~min}$ after Alloy 2 added. The addition of alloys and sampling procedures in the current experiments are shown in Figure 2. The addition amount of $\mathrm{Ni}-\mathrm{Mg}$ alloy and FeS remained the same in both experiments. Table 1 lists the compositions of raw materials used in the study.

Table 1. Compositions of raw materials (mass pct.).

\begin{tabular}{cccccccccc}
\hline Raw Material & Fe & Ni & Al & Mn & $\mathbf{C}$ & Si & Mg & S & Balance \\
\hline Industrial pure iron & 99.90 & 0.01 & 0.018 & 0.03 & 0.0021 & 0.01 & - & 0.003 & 0.035 \\
Mn-Fe alloy & 12.57 & & & 84.20 & 1.50 & 1.50 & - & 0.03 & \\
Pure aluminum & & & 99.90 & & & & & & 0.10 \\
Ni-Mg alloy & 0.93 & 80.12 & & & & & 17.98 & & 0.97 \\
FeS & 63.32 & & & & & & & 36.18 & 0.50 \\
\hline
\end{tabular}




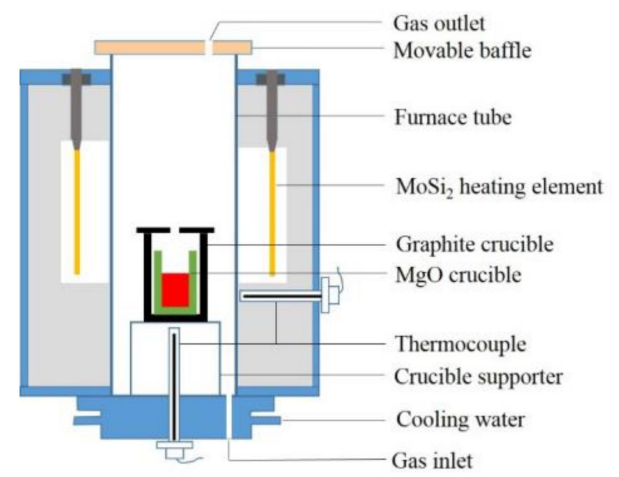

Figure 1. Schematic of tube furnace in the present experiments.

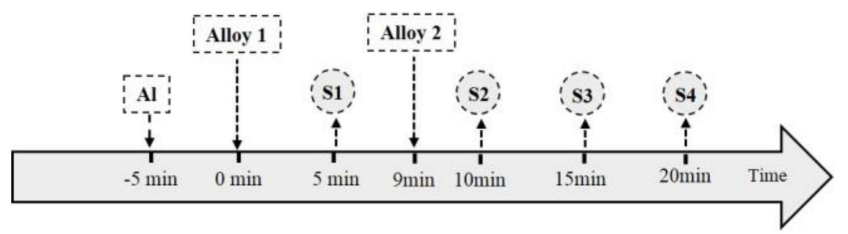

Figure 2. Addition of alloys and sampling procedure in the current experiments.

\subsection{Analysis Methods for Steels and Inclusions}

The residual steels in $\mathrm{MgO}$ crucibles were used to analyze the contents of sulfur, aluminum, manganese and magnesium by the inductively coupled plasma optical emission spectrometer (ICP-OES).

After all the experiments, the quenched samples were cut into cylinders $(\phi 5 \mathrm{~mm} \times 20 \mathrm{~mm})$. Then the cross-section of each sample was polished by 320\#, 600\#, 1000\#, 1500\#, 2000\# sandpapers in turn, and finally polished with the aid of abrasive paste until the surface was clean and free of scratches. Afterwards, the two-dimensional morphologies and compositions of inclusions in a cross section of each sample were analyzed by Phenom Prox (Eindhoven, The Netherlands). The system is the integrated platform of the field emission scanning election microscope (FE-SEM) and energy dispersive spectrometer (EDS).

\section{Results and Discussions}

\subsection{Chemical Compositions of Steels}

Table 2 lists the measured compositions of manganese, aluminum, magnesium and sulfur of steels. The results show that the mass fraction of manganese, aluminum and sulfur in the two experiments were at the same level. However, there was a significant difference in the mass fraction of magnesium between the two experiments. Exp. A contained 0.0007 pct. magnesium while Exp. B contained 0.0021 pct. magnesium.

Table 2. Chemical compositions of steels in different experiments (mass pct.).

\begin{tabular}{ccccc}
\hline Exp. & Mn & Al & Mg & S \\
\hline A & 1.41 & 0.035 & 0.0007 & 0.17 \\
B & 1.25 & 0.031 & 0.0021 & 0.15 \\
\hline
\end{tabular}

\subsection{Inclusions in Steels}

The inclusions observed in steels were oxide, sulfide and oxysulfide inclusions. Compositions of different types of inclusions are listed in Table 3. Note that all the types of inclusions were found in both sets of the experiments. 
Table 3. Composition ranges of different types of inclusions (mass pct.).

\begin{tabular}{cccccc}
\hline Types of Inclusions & Phase in Inclusions & $\mathbf{A l}_{\mathbf{2}} \mathbf{O}_{\mathbf{3}}$ & $\mathbf{M g O}$ & $\mathbf{M n S}$ & $\mathbf{M g S}$ \\
\hline $\mathrm{Al}_{2} \mathrm{O}_{3}$ & Oxide & $73-100$ & - & - & - \\
$\mathrm{MgO}$ & Oxide & - & $94-100$ & - & - \\
$\mathrm{Al}_{2} \mathrm{O}_{3}-\mathrm{MgO}$ & Oxide & $28-76$ & $24-72$ & - & - \\
$\mathrm{MnS}$ & Sulfide & - & - & 100 & 0 \\
$(\mathrm{Mg}, \mathrm{Mn}) \mathrm{S}$ & Sulfide & - & - & $40-90$ & $10-60$ \\
$\mathrm{Al}_{2} \mathrm{O}_{3}+\mathrm{MnS}$ & Oxide & 100 & - & - & - \\
$\mathrm{Al}_{2} \mathrm{O}_{3}-\mathrm{MgO}+\mathrm{MnS}$ & sulfide & - & - & 100 & - \\
$\mathrm{MgO}+(\mathrm{Mg}, \mathrm{Mn}) \mathrm{S}$ & Oxide & $21-81$ & $19-79$ & - & - \\
& Sulfide & - & - & 100 & - \\
& Oxide & - & 100 & - & - \\
\end{tabular}

Figure 3 shows the typical oxide inclusions detected in steels. The types of oxide inclusions were $\mathrm{Al}_{2} \mathrm{O}_{3}, \mathrm{MgO}-\mathrm{Al}_{2} \mathrm{O}_{3}$ and $\mathrm{MgO}$. As shown in Figure 3a, the morphology of $\mathrm{Al}_{2} \mathrm{O}_{3}$ inclusions was irregular and its size was about $1 \sim 2 \mu \mathrm{m}$. After magnesium addition, $\mathrm{MgO}$ inclusions formed immediately, as shown in Figure 3b. It can be seen that the morphology of $\mathrm{MgO}$ inclusions was roughly spherical and the size was about $1 \sim 2 \mu \mathrm{m}$. Figure $3 \mathrm{c}$ shows the typical $\mathrm{MgO}-\mathrm{Al}_{2} \mathrm{O}_{3}$ inclusions with irregular morphology. The elemental mappings showed that $\mathrm{Mg}$ and $\mathrm{Al}$ distributed uniformly in the inclusions. The mass fraction of $\mathrm{MgO}$ in the inclusions was in the range of 24-72 pct.
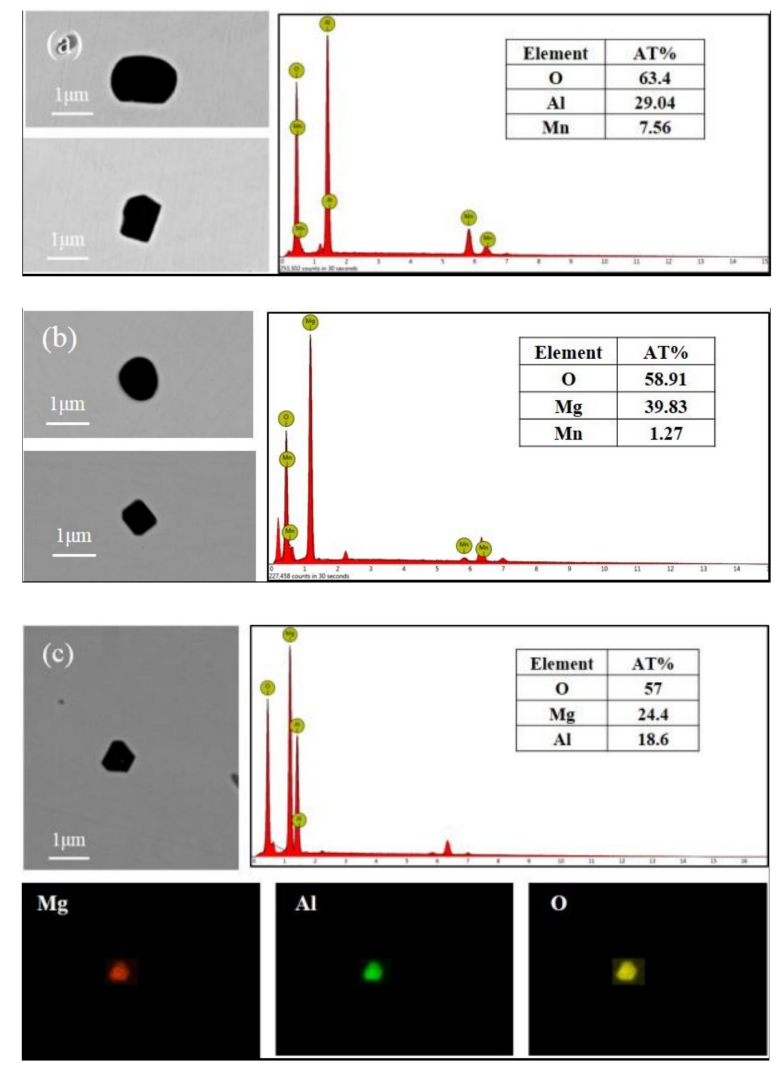

Figure 3. Typical oxide inclusions in steels: (a) $\mathrm{Al}_{2} \mathrm{O}_{3}$; (b) $\mathrm{MgO}$; (c) $\mathrm{MgO}-\mathrm{Al}_{2} \mathrm{O}_{3}$.

Figure 4 shows the typical sulfide inclusions in steels. Two types of sulfide inclusions, MnS and $(\mathrm{Mg}, \mathrm{Mn}) \mathrm{S}$ were observed. After sulfur addition, most of the observed MnS inclusions were elongated and distributed in chains or clusters, as shown in Figure 4a. Except for these MnS inclusions in clusters, some big spherical MnS inclusions distributed randomly in steels. The detected $(\mathrm{Mg}, \mathrm{Mn}) \mathrm{S}$ in steels 
were rectangular, as shown in Figure $4 \mathrm{~b}$. The elemental mappings indicated that $(\mathrm{Mg}, \mathrm{Mn}) \mathrm{S}$ was the solid solution composed of $\mathrm{MgS}$ and $\mathrm{MnS}$. The mass fraction of $\mathrm{MgS}$ in $(\mathrm{Mg}, \mathrm{Mn}) \mathrm{S}$ was in the range of 10-60 pct. According to Sims and Dahle [17], sulfide inclusions could be broadly classified into three types: i.e., (1) randomly dispersed globular sulfides (Type I), (2) rod-like fine sulfides (Type II), and (3) angular sulfides (Type III). The sulfide inclusions observed in Fe-Mn-S system by Ito et al. [18] were consistent with this classification. Oikawa et al. [19] investigated the evolution mechanism of sulfide inclusions with different morphologies. Their experimental results showed that globular MnS precipitated via a monotectic reaction and rod-like MnS formed through a eutectic reaction during solidification.
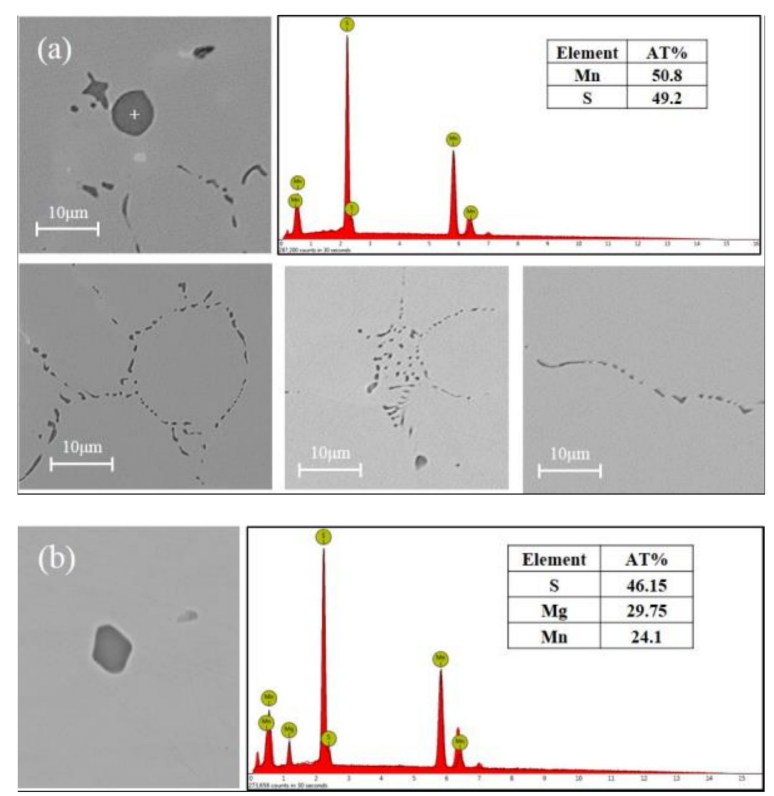

Figure 4. Typical sulfide inclusions in steels: (a) MnS; (b) (Mg, Mn)S.

Figure 5 are the typical oxysulfide inclusions in steels. The oxysulfide inclusions were mainly detected in samples after sulfur addition, which could be classified into three types: i.e., $\mathrm{Al}_{2} \mathrm{O}_{3}+\mathrm{MnS}_{\text {, }}$ $\mathrm{MgO}-\mathrm{Al}_{2} \mathrm{O}_{3}+\mathrm{MnS}$ and $\mathrm{MgO}+(\mathrm{Mg}, \mathrm{Mn}) \mathrm{S}$. The elemental mappings of the inclusions indicated that the oxysulfide were multiphase inclusions and composed of oxide and sulfide. The outer phase was MnS or $(\mathrm{Mg}, \mathrm{Mn}) \mathrm{S}$ and the inner phase was $\mathrm{Al}_{2} \mathrm{O}_{3}, \mathrm{MgO}$ or $\mathrm{MgO}-\mathrm{Al}_{2} \mathrm{O}_{3}$. Similar results were obtained in the study of Ohta et al. [20]. They pointed out that MnS crystallized and/or precipitated on the deoxidization particles during solidification.

The detected inclusion types in different samples were concluded in Table 4. In Exp. A, only $\mathrm{MgO}$ inclusions were found in the sample $\mathrm{A}-1$. After sulfur addition, $\mathrm{MgO}$ inclusions were modified to $\mathrm{MgO}-\mathrm{Al}_{2} \mathrm{O}_{3}$ inclusions. The main inclusions in the samples $\mathrm{A}-2$ to $\mathrm{A}-4$ were $\mathrm{MgO}-\mathrm{Al}_{2} \mathrm{O}_{3}+\mathrm{MnS}$ coexisted with a large amount of MnS. In Exp. B, sulfur was added into the molten steel before magnesium. $\mathrm{MnS}, \mathrm{Al}_{2} \mathrm{O}_{3}$ and $\mathrm{Al}_{2} \mathrm{O}_{3}+\mathrm{MnS}$ were detected in the sample $\mathrm{B}-1$ after sulfur addition. After magnesium addition, the main inclusions in the samples B-2 to B-4 were $\mathrm{MgO},(\mathrm{Mg}, \mathrm{Mn}) \mathrm{S}$, and $\mathrm{MgO}+(\mathrm{Mg}, \mathrm{Mn}) \mathrm{S}$ accompanied by a large amount of MnS. 

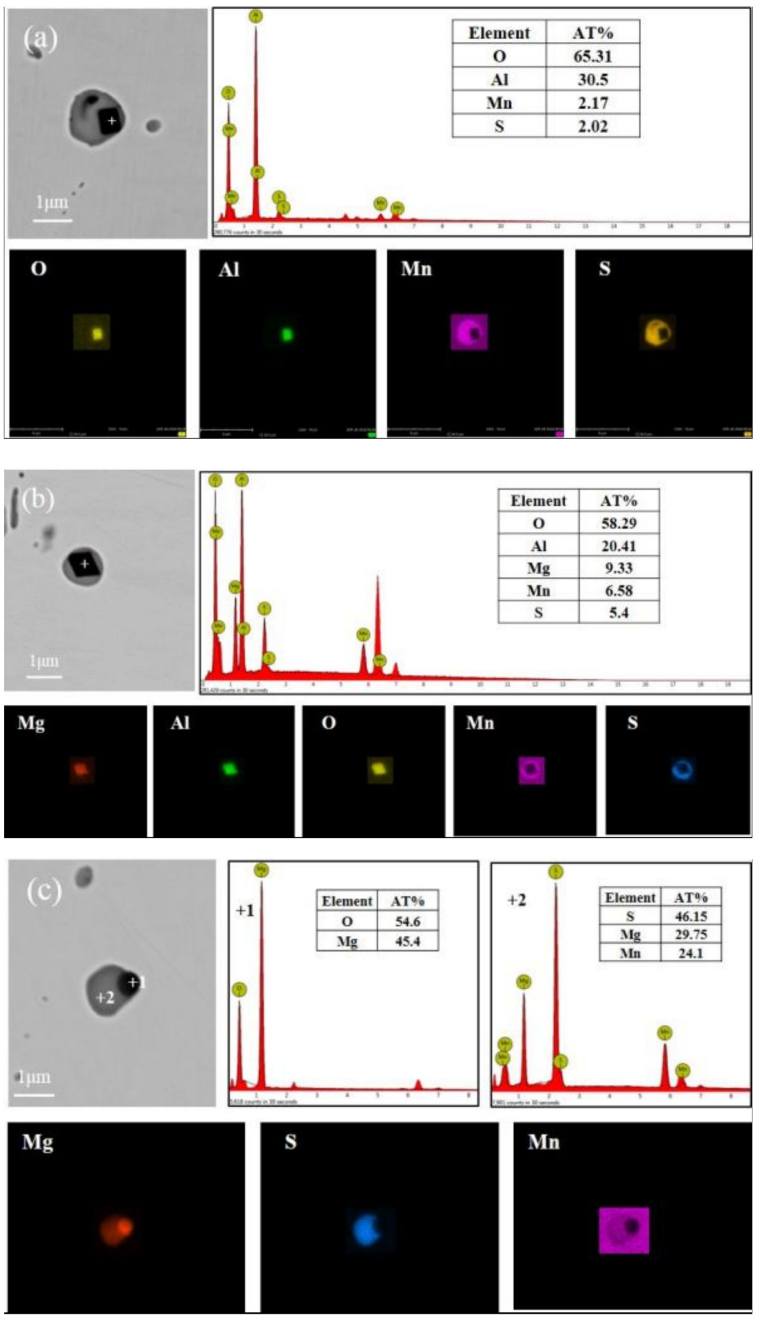

Figure 5. Typical oxysulfide inclusions in steels: (a) $\mathrm{Al}_{2} \mathrm{O}_{3}+\mathrm{MnS}$; (b) $\mathrm{MgO}-\mathrm{Al}_{2} \mathrm{O}_{3}+\mathrm{MnS}$; (c) $\mathrm{MgO}+(\mathrm{Mg}$, $\mathrm{Mn}) \mathrm{S}$.

Table 4. Types of inclusions in different samples.

\begin{tabular}{|c|c|c|c|c|c|c|c|c|c|}
\hline \multirow{2}{*}{$\begin{array}{l}\text { Types of } \\
\text { Inclusions }\end{array}$} & \multirow{2}{*}{ Size $(\mu \mathrm{m})$} & \multicolumn{4}{|c|}{ Sample Number in Exp. A } & \multicolumn{4}{|c|}{ Sample Number in Exp. B } \\
\hline & & 1 & 2 & 3 & 4 & 1 & 2 & 3 & 4 \\
\hline $\mathrm{Al}_{2} \mathrm{O}_{3}$ & $1 \sim 2$ & $x$ & $x$ & $x$ & $x$ & $\sqrt{ }$ & $x$ & $x$ & $x$ \\
\hline $\mathrm{MgO}$ & $1 \sim 2$ & $\sqrt{ } \sqrt{ }$ & $x$ & $\times$ & $\times$ & $x$ & $\sqrt{ }$ & $\sqrt{ }$ & $\sqrt{ }$ \\
\hline $\mathrm{Al}_{2} \mathrm{O}_{3}-\mathrm{MgO}$ & $1 \sim 2$ & $\times$ & $\sqrt{ }$ & $\sqrt{ }$ & $\sqrt{ }$ & $x$ & $x$ & $x$ & \\
\hline $\mathrm{MnS}$ & $1 \sim 10$ & $x$ & $\sqrt{ } \sqrt{ }$ & $\sqrt{ } \sqrt{ }$ & $\sqrt{ } \sqrt{ }$ & $\sqrt{ } \sqrt{ }$ & $\sqrt{ } \sqrt{ }$ & $\sqrt{ } \sqrt{ }$ & $\sqrt{ } \sqrt{ }$ \\
\hline$(\mathrm{Mg}, \mathrm{Mn}) \mathrm{S}$ & $1 \sim 2$ & $x$ & $x$ & $\times$ & $\times$ & $x$ & $\sqrt{ } \sqrt{ }$ & $\sqrt{ }$ & $\times$ \\
\hline $\mathrm{Al}_{2} \mathrm{O}_{3}+\mathrm{MnS}$ & $1 \sim 10$ & $x$ & $x$ & $x$ & $x$ & $\sqrt{ } \sqrt{ }$ & $\times$ & $x$ & $x$ \\
\hline $\mathrm{Al}_{2} \mathrm{O}_{3}-\mathrm{MgO}+\mathrm{MnS}$ & $1 \sim 10$ & $\times$ & $\sqrt{ } \sqrt{ }$ & $\sqrt{ } \sqrt{ }$ & $\sqrt{ } \sqrt{ }$ & $\times$ & $x$ & $x$ & $\times$ \\
\hline $\mathrm{MgO}+(\mathrm{Mg}, \mathrm{Mn}) \mathrm{S}$ & $1 \sim 10$ & $\times$ & $\times$ & $\times$ & $\times$ & $\times$ & $\sqrt{ } \sqrt{ }$ & $\sqrt{ }$ & $\sqrt{ }$ \\
\hline
\end{tabular}

' $\sqrt{ }$ ' main type of inclusions, ' $\sqrt{ }$ ' a small amount of inclusions, ' $\times$ ' trace amount of inclusions.

\subsection{Thermodynamic Calculations for Fe-Mg-Al-Mn-O-S System}

In the molten steel, the quasi-equilibrium was achieved due to favorable kinetic conditions. Hence, the thermodynamic calculations can be used to predict the formation and evolution of inclusions. In the thermodynamic calculations, FactSage ${ }^{\mathrm{TM}} 7.1$ program (developed by Thermfact/CRCT (Montreal, Canada) and GTT-Technologies (Achen, Germany)) was used to calculate the equilibrium products 
in Fe-Mg-Al-Mn-O-S system. The thermodynamic databases were FToxid, FactPS and FTmisc. The modification reactions of oxide inclusions are given in Equation (1) to (4).

$$
\begin{gathered}
4 \mathrm{Al}_{2} \mathrm{O}_{3}(\mathrm{~s})+3[\mathrm{Mg}]=3 \mathrm{MgO} \cdot \mathrm{Al}_{2} \mathrm{O}_{3}(\mathrm{~s})+2[\mathrm{Al}] \\
\log K_{3}=34.37-46950 / T \\
\mathrm{MgO} \cdot \mathrm{Al}_{2} \mathrm{O}_{3}(\mathrm{~s})+3[\mathrm{Mg}]=4 \mathrm{MgO}(\mathrm{s})+2[\mathrm{Al}] \\
\log \mathrm{K}_{6}=33.09-50880 / T
\end{gathered}
$$

where $[i]$ is the dissolved $i(i=\mathrm{Mg}, \mathrm{Al}, \mathrm{Mn}, \mathrm{S}, \mathrm{O})$ in the molten steel, (s) is the solid reactor or product, $K$ is the reaction equilibrium constant, $T$ is the Kelvin temperature. The formation reactions of sulfide inclusions can be expressed by Equations (5) to (8).

$$
\begin{gathered}
{[\mathrm{Mg}]+[\mathrm{S}]=\mathrm{MgS}(\mathrm{s})} \\
\log K_{9}=-11.27+28893 / \mathrm{T} \\
{[\mathrm{Mn}]+[\mathrm{S}]=\mathrm{MnS}(\mathrm{s})} \\
\log K_{12}=4.63-8794 / T
\end{gathered}
$$

Figure 6 shows the stability diagram of inclusions for Fe-Mg-Al-Mn-O-S system at $1600{ }^{\circ} \mathrm{C}$. The equilibrium products are plotted on the diagram and the phase boundaries are represented as heavy lines. The equilibrium products contain $\mathrm{Al}_{2} \mathrm{O}_{3}$, spinel $\left(\mathrm{MgAl}_{2} \mathrm{O}_{4}\right), \mathrm{MgO}$ and $\mathrm{MeS}\left(\mathrm{Mg}_{0.9} \mathrm{Mn}_{0.1} \mathrm{~S}\right)$. The calculation results clearly predict the precipitation of magnesium sulfide $\mathrm{MeS}$ containing a quantity of MnS, which is consistent with the experimental results. The stoichiometry of MeS is calculated to be $\mathrm{Mg}_{0.9} \mathrm{Mn}_{0.1} \mathrm{~S}$. MeS can coexist with $\mathrm{MgO}$ or spinel. The green shadow region in Figure 6 with [Al] content below 0.23 pct. and $[\mathrm{Mg}]$ content higher than 0.0024 pct. is the stability region of $\mathrm{MgO}+\mathrm{MeS}$. Instead, the yellow shadow region with [Al] content above 0.23 pct. and $[\mathrm{Mg}]$ content exceeding 0.0016 pct. is the stability region of spinel+MeS. In addition, the stability regions of $\mathrm{Al}_{2} \mathrm{O}_{3}$, spinel and $\mathrm{MgO}$ without MeS also exist with relatively lower $[\mathrm{Mg}]$ content.

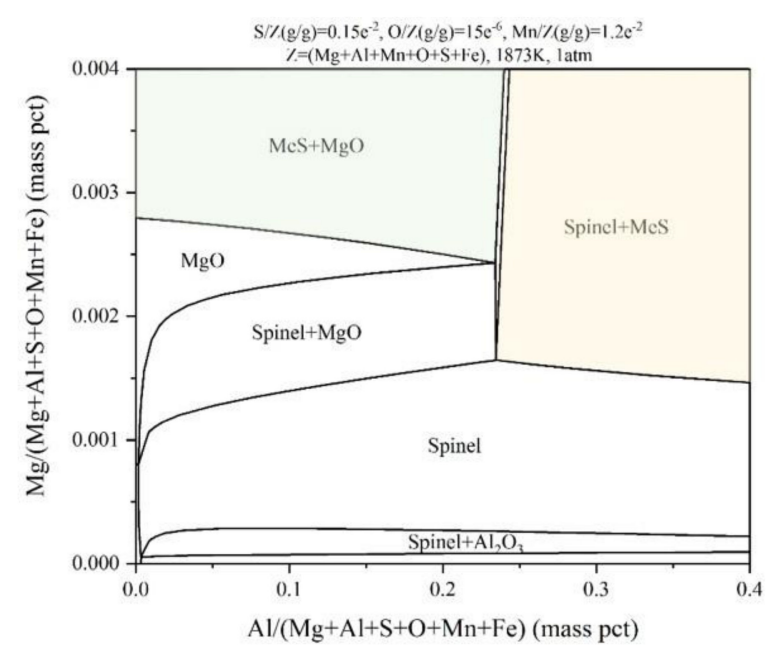

Figure 6. Stability diagram for Fe-Mg-Al-Mn-O-S system at $1600{ }^{\circ} \mathrm{C}\left(\mathrm{MeS}: \mathrm{Mg}_{0.9} \mathrm{Mn}_{0.1} \mathrm{~S}\right.$, Spinel: $\left.\mathrm{MgAl}_{2} \mathrm{O}_{4}\right)$.

Figure 7 shows the effect of magnesium addition on the evolution of inclusions after sulfur addition at $1600{ }^{\circ} \mathrm{C}$. The initial composition of steel is Fe-0.03Al-1.2Mn-0.0015O-0.15S in mass pct. The result indicates that magnesium has a significant effect on the equilibrium products. $\mathrm{Al}_{2} \mathrm{O}_{3}$ is modified to spinel when the mass fraction of $[\mathrm{Mg}]$ is below 0.0012 pct. However, when the mass fraction of $[\mathrm{Mg}]$ 
exceeds 0.0012 pct., $\mathrm{MgO}$ forms with the decomposition of spinel. It is noticed that MeS precipitates from the molten steel when the mass fraction of $[\mathrm{Mg}]$ is higher than 0.0027 pct. It is thus concluded that the formation sequence of inclusions is $\mathrm{Al}_{2} \mathrm{O}_{3} \rightarrow$ spinel $\rightarrow \mathrm{MgO} \rightarrow \mathrm{MeS}$ with the increase of [Mg] content in steel.

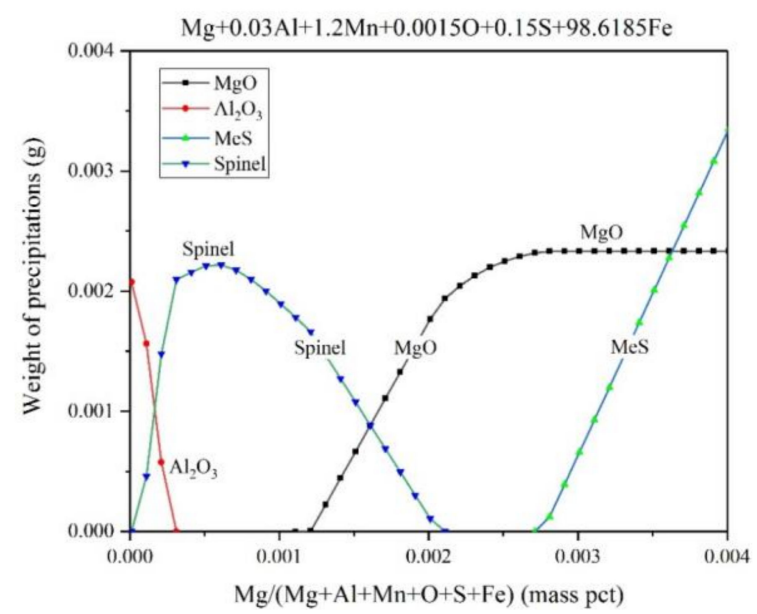

Figure 7. Effect of magnesium addition on the evolution of inclusions after sulfur addition (MeS: $\mathrm{Mg}_{0.9} \mathrm{Mn}_{0.1}$ S, Spinel: $\left.\mathrm{MgAl}_{2} \mathrm{O}_{4}\right)$.

Figure 8 shows the effect of sulfur addition on the evolution of inclusions in Al-Mg deoxidized steel at $1600{ }^{\circ} \mathrm{C}$. The initial composition of steel is Fe-0.003Mg+0.03Al+1.2Mn+0.0015O in mass pct. When the mass fraction of [S] in steel is below 0.1 pct., only $\mathrm{MgO}$ exists in the molten steel. If the mass fraction of $[S]$ is in the range $0.1-0.48$ pct., MeS will precipitate from the molten steel, which results in a decrease of $[\mathrm{Mg}]$ content. When the mass fraction of [S] is about 0.48-0.5 pct., $\mathrm{MgO}$ starts to decompose with the formation of spinel and MeS, as shown in Equation (9). When the mass fraction of [S] is higher than 0.5 pct., spinel and MeS coexist in the molten steel. Therefore, the effect of sulfur addition on the evolution of inclusions can be ignored if trace amount of sulfur is added into steel, while excessive addition of sulfur will result in the transformation of $\mathrm{MgO}$ to spinel accompanied by the formation of MeS.

$$
\begin{gathered}
4 \mathrm{MgO}(\mathrm{s})+2[\mathrm{Al}]+3[\mathrm{~S}]=\mathrm{MgO} \cdot \mathrm{Al}_{2} \mathrm{O}_{3}(\mathrm{~s})+3 \mathrm{MgS}(\mathrm{s}) \\
\log K_{15}=-66.9+137559 / \mathrm{T}
\end{gathered}
$$

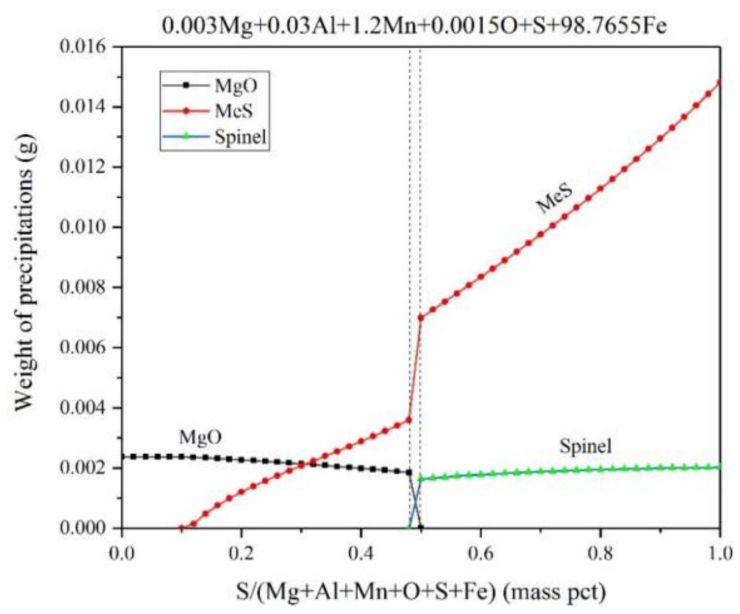

Figure 8. Effect of sulfur addition on the evolution of inclusions after magnesium addition (MeS: $\mathrm{Mg}_{0.9} \mathrm{Mn}_{0.1}$ S, Spinel: $\left.\mathrm{MgAl}_{2} \mathrm{O}_{4}\right)$. 
Owing to the rapid cooling rate, some significant transformations during solidification cannot be detected in the experimental results. In order to investigate the evolution of secondary inclusions, thermodynamic calculations were performed from $1600{ }^{\circ} \mathrm{C}$ to $1450{ }^{\circ} \mathrm{C}$.

Figure 9 predicts the evolution of inclusions during solidification for Fe-Mg-Al-Mn-O-S system. The initial steel composition is $\mathrm{Fe}-0.003 \mathrm{Mg}-0.03 \mathrm{Al}-1.2 \mathrm{Mn}-0.0015 \mathrm{O}-1.5 \mathrm{~S}$ in mass pct. The liquids temperature $\left(1530^{\circ} \mathrm{C}\right)$ and solidus temperature $\left(1500^{\circ} \mathrm{C}\right)$ are presented as dotted lines, respectively. The primary inclusions in molten steel are $\mathrm{MgO}$ and $\mathrm{MeS}$ before solidification. At the initial stage of solidification $\left(1530{ }^{\circ} \mathrm{C}\right.$ to $\left.1520^{\circ} \mathrm{C}\right), \mathrm{MgO}$ and $\mathrm{MeS}$ were stable. At the middle stage of solidification $\left(1520^{\circ} \mathrm{C}\right.$ to $\left.1510^{\circ} \mathrm{C}\right), \mathrm{MgO}$ reacts with [Al] and [S] to form spinel and $\mathrm{MeS}$ through Equation (9). At the last stage of solidification $\left(1510^{\circ} \mathrm{C}\right.$ to $\left.1500{ }^{\circ} \mathrm{C}\right)$, large amount of $\mathrm{MnS}$ precipitate from the residual liquid steel. The equilibrium products after solidification are spinel, MeS and MnS.

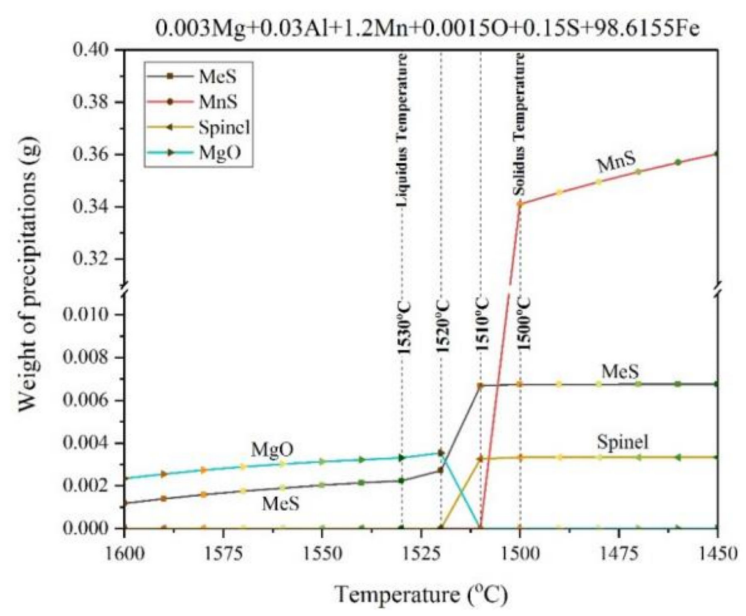

Figure 9. Equilibrium precipitation of inclusions during solidification for Mg-Al-Mn-O-S molten steel (MeS: $\mathrm{Mg}_{0.9} \mathrm{Mn}_{0.1}$ S, Spinel: $\mathrm{MgAl}_{2} \mathrm{O}_{4}$ ).

\subsection{Formation and Transient Evolution Mechanism of Inclusions}

According to the experimental results and thermodynamic calculations, the evolution mechanism of inclusions with different adding order of magnesium and sulfur is described in Figure 10. In the first case, magnesium is added before sulfur, as shown in Figure 10a. In the second case, sulfur is added before magnesium, as shown in Figure 10b.

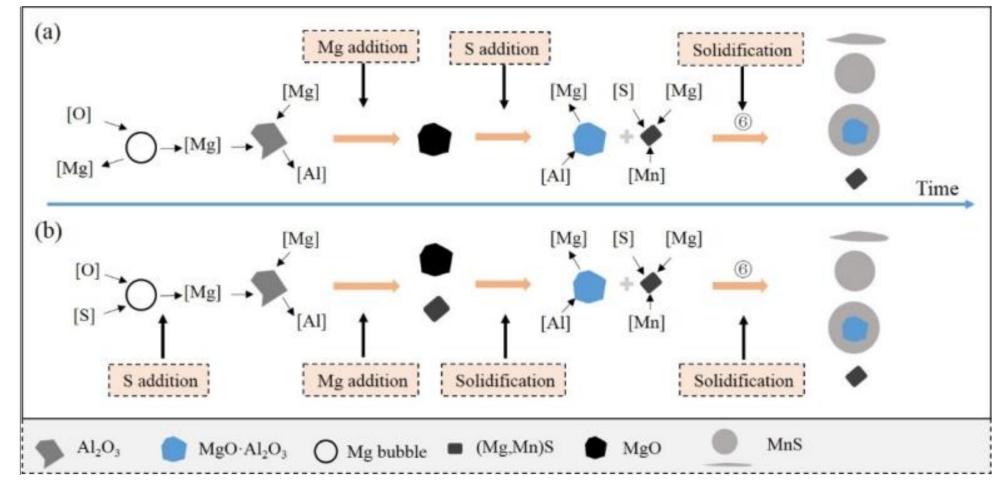

Figure 10. Formation and evolution mechanism of inclusions with different adding order of magnesium and sulfur for Fe-Mg-Al-Mn-O-S system.

The melting and boiling temperature of magnesium at atmospheric pressure are $650{ }^{\circ} \mathrm{C}$ and $1090{ }^{\circ} \mathrm{C}$, respectively. Therefore, magnesium will vaporize rapidly at steelmaking temperature. The generated bubbles tend to be dissolved into the molten steel during the floating process. The reaction 
can be expressed as Equation (11). Different adding order of magnesium would result in a difference in the yielding rate of magnesium. The compositions analysis result in Table 2 shows that the magnesium content in Exp. A is much lower than that in Exp. B.

In the case of magnesium added before sulfur, $\mathrm{MgO}$ forms around the magnesium bubbles after magnesium addition, as shown in Equation (13). With the rapid diffusion of [Mg] in molten steel, $\mathrm{Al}_{2} \mathrm{O}_{3}$ is modified to $\mathrm{MgO}$ by Equation (15). After the addition of sulfur, $\mathrm{MgO}$ is transferred to spinel accompanied by $\mathrm{MeS}$, as presented in Equation (9). The main reason is that the formation of MeS decreases the $[\mathrm{Mg}]$ content in steel, which forces the reaction balance of Equation (3) moving toward spinel production. In the process of solidification, MnS crystallize from the saturated liquid steel and spinel inclusions work as the heterogeneous nucleation sites for MnS.

$$
\begin{gathered}
\operatorname{Mg}(\mathrm{g})=[\mathrm{Mg}] \\
\log K_{21}=-0.724-974 / T \\
\operatorname{Mg}(\mathrm{g})+[\mathrm{O}]=\mathrm{MgO}(\mathrm{s}) \\
\log K_{23}=-10.88+32022 / \mathrm{T} \\
\mathrm{Al}_{2} \mathrm{O}_{3}(\mathrm{~s})+3[\mathrm{Mg}]=3 \mathrm{MgO}(\mathrm{s})+2[\mathrm{Al}] \\
\log \mathrm{K}_{25}=24.46-31200 / T
\end{gathered}
$$

In the case of sulfur added before magnesium, the balances of [Mg]-[O] and [Mg]-[S] take place at the same time. $\mathrm{MgO}$ and $\mathrm{MeS}$ precipitate simultaneously after magnesium addition. During solidification, $\mathrm{MgO}$ is transformed into spinel and $\mathrm{MeS}$ before the precipitation of MnS with the enrichment of [S] in the liquid steel.

\section{Conclusions}

In this work, laboratory experiments and thermodynamic calculations were performed to investigate the effect of magnesium and sulfur adding order on the evolution of inclusions in Al-killed free-cutting steel. The main conclusions are summarized as follows.

(1) In the case of magnesium added before sulfur, $\mathrm{MgO}$ is transformed into spinel immediately after sulfur addition, while this transformation is calculated to take place during the equilibrium solidification with the enrichment of [S] in the case of sulfur added before magnesium.

(2) Under the experimental condition, $\mathrm{MgS}$ precipitates with a quantity of MnS and the stoichiometry is calculated to be $\left(\mathrm{Mg}_{0.9} \mathrm{Mn}_{0.1}\right) \mathrm{S}$.

(3) The stability diagram for Fe-Mg-Al-1.2Mn-0.0015O-0.15S system is obtained and the thermodynamic calculation results show that the equilibrium products are $\mathrm{Al}_{2} \mathrm{O}_{3} /$ spinel/MgO/MeS at $1600{ }^{\circ} \mathrm{C}$.

Author Contributions: Resources, H.X., J.X. and C.L.; Writing-original draft, Y.M. and Q.Z.; Writing-review \& editing, Y.M. and Q.Z.

Funding: This research was funded by National Key R \& D Program of China (Grant No. 2017YFC0805100) and National Natural Science Foundation of China (Grant No. NSFC 51674069).

Conflicts of Interest: The authors declare no conflict of interest.

\section{References}

1. Laizhu, J.; Kun, C.; Hänninen, H. Effects of the composition, shape factor and area fraction of sulfide inclusions on the machinability of re-sulfurized free-machining steel. J. Mater. Process. Technol. 1996, 58, 160-165. [CrossRef] 
2. Ånmark, N.; Karasev, A.; Jönsson, P.G. The effect of different non-metallic inclusions on the machinability of steels. Materials 2015, 8, 751-783. [CrossRef] [PubMed]

3. Yaguchi, H. Effect of MnS inclusion size on machinability of low-carbon, leaded, resulfurized free-machining steel. J. Appl. Metalwork. 1986, 4, 214-225. [CrossRef]

4. Fujiwara, J. Cutting mechanism of sulfurized free-machining steel. In Scanning Electron Microscopy; IntechOpen: London, UK, 2012.

5. Pollard, B. Effect of manganese content on sulphide shape control by zirconium in steel. Met. Technol. 1974, 1, 343-347. [CrossRef]

6. Kim, H.; Kang, M.; Shin, S.Y.; Lee, S. Alligatoring phenomenon occurring during hot rolling of free-machining steel wire rods. Mater. Sci. Eng. A 2013, 568, 8-19. [CrossRef]

7. Luyckx, L.; Bell, J.R.; McLean, A.; Korchynsky, M. Sulfide shape control in high strength low alloy steels. Metall. Trans. 1970, 1, 3341-3350.

8. Jiang, L.; Cui, K. Quantitative study of modification of sulphide inclusions by calcium and its effect on the impact toughness of a resulfurized alloy steel. Steel Res. 1997, 68, 163-168. [CrossRef]

9. Feild, A. Effect of zirconium on hot-rolling properties of high-sulfur steels and the occurrence of zirconium sulfide. Trans. Am. Inst. Min. Metall. Eng. 1924, 70, 201-223.

10. Koch, W.; Artner, E. Beitrag zur Isolierung von Sulfiden in Stählen. Arch. Eisenhüttenwes. 1958, 29, 737-744. [CrossRef]

11. Yang, J.; Okumura, K.; Kuwabara, M.; Sano, M. Behavior of magnesium in the desulfurization process of molten iron with magnesium vapor produced in-situ by aluminothermic reduction of magnesium oxide. ISIJ Int. 2002, 42, 685-693. [CrossRef]

12. Hosohara, S.; Kato, Y.; Nakato, H.; Sorimachi, K. The effect of pressure in the atmosphere on desulfurization of hot metal and reaction mechanism with magnesium. Tetsu-to-hagane 2002, 88, 129-135. [CrossRef]

13. Chen, B.; Jiang, M.; Wang, C.-g.; Wang, X.-h. Theoretical research of applying Mg to ultra clean steel production. Iron Steel 2007, 7, 007. (In Chinese)

14. Zhang, T.S.; Min, Y.; Jiang, M.F. Effect of magnesium addition on evolution of inclusions in Mn-Si-Al deoxidized molten steels. Chem. Extr. Metall. Pyrometall. 2014, 54, 161-169.

15. Park, J.H.; Todoroki, H. Control of $\mathrm{MgO} \cdot \mathrm{Al}_{2} \mathrm{O}_{3}$ spinel inclusions in stainless steels. ISIJ Int. 2010, 50, 1333-1346. [CrossRef]

16. Zhang, L.; Ren, Y.; Duan, H.; Yang, W.; Sun, L. Stability Diagram of Mg-Al-O System Inclusions in Molten Steel. Metall. Mater. Trans. B 2015, 46, 1809-1825. [CrossRef]

17. Sims, C.; Dahle, F. Effect of aluminum on the properties of medium carbon cast steel. Trans. Am. Foundry Soc. 1938, 46, 65-132.

18. Ito, Y.; Yonezawa, N.; Matsubara, K. Effect of Carbon on the Composition of Eutectic Conjugation in the Fe-Mn-S System and Equilibrium Composition of Sulphide in Solid Steel. Trans. Iron Steel Inst. Jpn. 1980, 20, 301-308.

19. Oikawa, K.; Ohtani, H.; Ishida, K.; Nishizawa, T. The control of the morphology of MnS inclusions in steel during solidification. ISIJ Int. 1995, 35, 402-408. [CrossRef]

20. Ohta, H.; Suito, H. Precipitation and dispersion control of $\mathrm{MnS}$ by deoxidation products of $\mathrm{ZrO}_{2}, \mathrm{Al}_{2} \mathrm{O}_{3}$, $\mathrm{MgO}$ and $\mathrm{MnO}-\mathrm{SiO}_{2}$ particles in Fe-10mass\% Ni alloy. ISIJ Int. 2006, 46, 480-489. [CrossRef]

(C) 2018 by the authors. Licensee MDPI, Basel, Switzerland. This article is an open access article distributed under the terms and conditions of the Creative Commons Attribution (CC BY) license (http:/ / creativecommons.org/licenses/by/4.0/). 